\title{
Assessment of REDD+ MRV Capacity in Developing Countries and Implications under the Paris Regime
}

\author{
Raehyun Kim ${ }^{1, *(1)}$, Dong-hwan Kim ${ }^{1}$, Seongsil Cho ${ }^{1}$, Eunho Choi ${ }^{1}$, Jinwoo Park ${ }^{2}$, Sue Kyoung Lee ${ }^{3}(\mathbb{C}$ \\ and Yowhan Son ${ }^{4}$ \\ 1 Division of Global Forestry, National Institute of Forest Science, Seoul 02455, Korea; \\ donghwan110@korea.kr (D.-h.K.); miracho0126@korea.kr (S.C.); ehchoi710@korea.kr (E.C.) \\ 2 Department of Forest Management, College of Forest and Environmental Science, Kangwon National \\ University, Chuncheon 24341, Korea; pjw@kangwon.ac.kr \\ 3 Division of Climate Technology Cooperation, Green Technology Center, Seoul 04554, Korea; sklee@gtck.re.kr \\ 4 Division of Environmental Science and Ecological Engineering, College of Life Science and Biotechnology, \\ Korea University, Seoul 20841, Korea; yson@korea.ac.kr \\ * Correspondence: rhkim@korea.kr; Tel.: +82-10-5327-7612
}

Citation: Kim, R.; Kim, D.-h.; Cho, S.; Choi, E.; Park, J.; Lee, S.K.; Son, Y. Assessment of REDD+ MRV Capacity in Developing Countries and Implications under the Paris Regime. Land 2021, 10, 943. https://doi.org/ 10.3390/land10090943

Academic Editors: Joshua D. Fisher and Summer Allen

Received: 4 August 2021

Accepted: 3 September 2021

Published: 7 September 2021

Publisher's Note: MDPI stays neutra with regard to jurisdictional claims in published maps and institutional affiliations.

Copyright: (c) 2021 by the authors. Licensee MDPI, Basel, Switzerland. This article is an open access article distributed under the terms and conditions of the Creative Commons Attribution (CC BY) license (https:/ / creativecommons.org/licenses/by/ $4.0 /)$.

\begin{abstract}
The United Nations Framework Convention on Climate Change (UNFCCC) recognized the importance of forests in combating climate change and agreed upon financial support for REDD+ activities in developing countries through the Warsaw REDD+ Framework (WRF). The REDD+ activities for conserving carbon stored in forests to reduce GHG emissions and to enhance the carbon sink function of forests are expected to serve as an important means for achieving the climatic goal. In this study, a set of criteria was devised to assess the REDD+ Measuring, Reporting, and Verifying (MRV) implementation capabilities of developing countries, which was applied to analyze the REDD+ MRV levels in REDD+ countries. Based on the Forest Reference Emission Level/Forest Reference Level (FREL/FRL), National Strategy (NS), National Forest Monitoring System (NFMS) and Safeguard Information Summary (SIS) the countries submitted, 36 REDD+ countries submitted only the FREL/FRL (Group I), while 5 countries fulfilled the WRF requirements and registered REDD+ reduction results (Group II), and 6 received Results-Based Payments (RBP) (Group III). From longest to shortest, the periods for which the International Fund provided support were arranged in the order of Group III, II, and I, verifying the relative importance of international support. From highest to lowest, the overall MRV capability was also arranged in the order of Group III, II, and I, although Group I or Group II was at a higher level than the other groups in some elements. REDD+ countries in the Readiness Phase (Group I) would aim to have the MRV capabilities of Groups II and III to receive RBP, and international support for REDD+ MRV capacity building could enable them to do. However, in addition to the receipt of RBP, REDD+ should be reflected in the Nationally Determined Contribution (NDC) as consistent reduction results at the national GHG inventory level, and the advancement of REDD+ MRV is expected to be a necessary and sufficient condition for REDD+ cooperation under the Paris Agreement cooperative approach framework. For the following groups, international cooperation is essential. Countries in the Readiness Phase need to be supported with the establishment of an MRV framework, which will enable them to achieve REDD+ to receive RBP and be reflected in NDCs. For REDD+ countries that have thus far met the WRF requirements, the REDD+ scope needs to be upscaled to national levels, and the MRV system should be further advanced to establish a cooperative approach system that can achieve more ambitious reduction targets through forests.
\end{abstract}

Keywords: Warsaw REDD+ Framework; MRV; deforestation; United Nations Framework Convention on Climate Change; nature-based solution 


\section{Introduction}

To achieve the climate goal of holding the increase in the global average temperature to well below $2{ }^{\circ} \mathrm{C}$ above pre-industrial levels and pursuing efforts to limit the temperature increase to $1.5^{\circ} \mathrm{C}$ above pre-industrial levels [1], it is critical to prevent deforestation and the degradation of forests and promote their capacity as carbon sinks through sustainable management. Reaching this climate goal requires reducing carbon dioxide emissions to less than 750 billion tons by the end of this century [2-4], and land systems, particularly forests, are known to absorb $28 \%$ of the 39 billion tons of anthropogenic $\mathrm{CO}_{2}$ annually [5]. The damage caused by the destruction of forests on the Earth is estimated to amount to more than 3 trillion tons of $\mathrm{CO}_{2}$ emissions [6,7]. Deforestation and forest degradations could create detrimental effects in forest functions in regulating the atmosphere, causing greenhouse gas (GHG) emissions from the forest sector to increase, thereby reducing the chances of achieving the climate goal.

The Kyoto Regime under the United Nations Framework Convention on Climate Change (UNFCCC) recognized the importance of forests in combating climate change, and the Conference of the Parties agreed on establishing the Warsaw REDD+ Framework (WRF) for activities to reduce emissions from deforestation and forest degradation and stating the role of conservation, sustainable management of forests and enhancement of forest carbon stocks in developing countries [8]. REDD+ countries are eligible to receive results-based payments (RBPs) for reduction outcomes under the WRF and, therefore, the countries should build an efficient Measurement, Reporting and Verifying (MRV) system at the national level to monitor GHG emissions and removals about REDD+ activities, according to the WRF.

However, establishing an MRV system is a huge challenge for developing countries. Of the 62 REDD+ countries, 11 countries have registered reduction results, and only 6 countries have received RBPs in accordance with the WRF. Additionally, under the Paris Agreement, developing countries belonging to the non-Annex I class in the Kyoto Regime submitted a Nationally Determined Contribution (NDC), which contains the emissions reduction target to reach by 2030 . The importance of establishing and empowering the MRV framework in the forest sector has further grown because countries might consider internationally transferred mitigation outcomes (ITMOs) to implement an NDC based on the cooperative approaches of Article 6 of the Paris Agreement.

In this context, international support is imperative to strengthen the MRV capabilities of developing countries to implement REDD+. Therefore, the assessment of MRV capabilities and understanding the status of implementation for each REDD+ country are essential for ensuring effective technical and financial cooperation. Precedent studies have suggested criteria and indicators for evaluating REDD+ MRV capabilities [9-11]. However, the studies were conducted before the adoption of WRF at the 19th Conference of the Parties to the UNFCCC. Thus, there are limitations to practically evaluating the required MRV level on the reduction results to RBPs in accordance with the WRF. Consequently, the purpose of this study was to develop modified criteria and indicators for REDD+ MRV evaluation based on the precedent criteria and indicators, taking the items and content of the requirements for participating in REDD+ under the current UNFCCC provisions into consideration. The proposed criteria and indicators were then applied to 47 countries that submitted national reports related to REDD+ or registered reductions in the UNFCCC REDD+ platform to analyze their capabilities to implement REDD+ MRV.

\section{Materials and Methods}

\subsection{National Report on REDD+MRV}

Countries that participate in the WRF are required to comply with the modality and procedure of the Warsaw Framework for REDD+ as defined by COP19: (1) develop a national strategy or action plan (NS or AP); (2) submit a National Forest Reference Emission Level/Forest Reference Level (FREL/FRL) and receive approval through technical evaluation; (3) establish a National Forest Monitoring System (NFMS); and (4) submit a 
Safeguard Information Summary (SIS) $[8,12,13]$. REDD+ reduction results are calculated based on these data and are reported through the biennial update report (BUR) to be examined by international consultation and analysis (ICA) prior to final approval [14]. Once final approval is given, the REDD+ reduction results are registered on the REDD+ web platform, leading to a stage where the RBPs can be received.

Through reviewing national reports received under the MRV system of the UNFCCC REDD+ mechanism described above, we analyzed the national MRV levels, and a comparison was made between country reports of Global Forest Resources Assessments (FRAs) by the Food and Agriculture Organization (FAO), with relevant statistics and information to ensure transparency in the national reports. The following table shows a list of the reports and their sources by key analytical elements (Table 1).

Table 1. Source of data collected for the analysis.

\begin{tabular}{|c|c|c|}
\hline Elements & National Report & Source \\
\hline NS & National REDD+ strategy & \multirow{6}{*}{$\begin{array}{l}\text { UN REDD+ } \\
\text { web platform }\end{array}$} \\
\hline NFMS & Submission or modified submission on proposed FREL/FRL & \\
\hline FREL/FRL & Report on the technical assessment of the proposed FREL/FRL & \\
\hline SIS & Safeguards information summary & \\
\hline \multirow{3}{*}{ Others } & Reduction results & \\
\hline & Biennial update report (Annex: REDD+ results) & \\
\hline & Global Forest Resources Assessments: country reports & FAO \\
\hline
\end{tabular}

\subsection{REDD+MRV Evaluation Framework}

To evaluate the MRV capacities of the REDD+ countries, the methods and criteria to assess national forest monitoring capability in [9] were modified and supplemented in this study to meet the provisions of the Warsaw Framework for REDD+ adopted in COP13. The 15 indicators in [9] were defined for GHG inventory, forest monitoring capacity, cooperation, and specific characteristics and requirements to evaluate the monitoring and reporting capacities of developing countries [9]. However, these indicators were developed before the adoption of the WRF; thus, the UNFCCC national reports from developing countries available for evaluation at the time only included the FRA and the Readiness Project Idea Notes submitted to the Forest Carbon Partnership Facility (FCPF), other than National Communications (NC). On the other hand, this study identified 13 indicators in 6 categories, reflecting the WRF's requirements for REDD+ implementation criteria in developing countries, to evaluate national MRV capabilities through NS, NFMS, FREL/FRL, and Safeguard (Table 2). The indicators used to evaluate the engagement in UNFCCC REDD+ were based on the indicators offered by [9], but the evaluation criteria were revised with an emphasis on UNFCCC documents. 
Table 2. Indicators of the REDD+ MRV evaluation framework.

\begin{tabular}{|c|c|c|c|}
\hline & Key Requirement & Indicator & Description (Score) \\
\hline $\begin{array}{l}\text { National Reports or } \\
\text { Submissions }\end{array}$ & $\begin{array}{l}\text { Understanding of } \\
\text { international UNFCCC } \\
\text { negotiations and the REDD+ } \\
\text { process }\end{array}$ & $\begin{array}{c}\text { Engagement in UNFCCC } \\
\text { REDD+ }\end{array}$ & $\begin{array}{l}\text { Low (1.00): National Communication (NC) or Biennial } \\
\text { Update Report } \\
\text { Intermediate (2.33): Forest Reference Emission Level or } \\
\text { Forest Reference Level submission } \\
\text { High (3.67): Submission of a reduction result at least once } \\
\text { Very high (5.00): Submission of a reduction result more } \\
\text { than once }\end{array}$ \\
\hline National Strategy & $\begin{array}{c}\text { Issues to be considered as } \\
\text { agreed by the Cancun } \\
\text { Agreement }\end{array}$ & $\begin{array}{c}\text { The number of reported } \\
\text { issues }\end{array}$ & $\begin{array}{l}\text { N/A (0.00): Not available (not submitted) } \\
\text { Low (1.00): Less than three reported among five issues that } \\
\text { include "the drivers of deforestation and forest } \\
\text { degradation," "land tenure issues," "forest governance } \\
\text { issues," "gender consideration" and "safeguards" } \\
\text { Intermediate (3.00): Three or more issues are reported } \\
\text { High (5.00): All of them are reported }\end{array}$ \\
\hline National & Forest definition & $\begin{array}{c}\text { Consistency of forest } \\
\text { definition within submitted } \\
\text { reports }\end{array}$ & $\begin{array}{l}\text { Low (1.00): All forest definitions differ from each other } \\
\text { (REDD+, NC or BUR, FAO-FRA) } \\
\text { Intermediate (2.33): Forest definition in REDD+ } \\
\text { corresponds to FAO-FRA only } \\
\text { High (3.67): Forest definition in REDD+ corresponds to NC } \\
\text { or BUR only } \\
\text { Very high (5.00): All definitions correspond to each other }\end{array}$ \\
\hline Monitoring System & $\begin{array}{l}\text { Forest area change } \\
\text { monitoring capacity }\end{array}$ & $\begin{array}{l}\text { Forest area change time } \\
\text { series and remote sensing } \\
\text { capabilities }\end{array}$ & $\begin{array}{l}\text { Very low (1.00): No forest cover map } \\
\text { Low (2.00): A forest cover map (external) } \\
\text { Intermediate (3.00): Multiple forest cover maps (external) } \\
\text { High (4.00): A forest cover map in-house or multiple maps, } \\
\text { with the latest before } 2000 \\
\text { Very high (5.00): Most recent regular forest area mapping } \\
\text { after } 2000\end{array}$ \\
\hline \multirow{6}{*}{ FREL/FRL } & \multirow{4}{*}{ Carbon stock assessment } & Activity Data (AD) & $\begin{array}{l}\text { Low (1.00): Total area for forest land only } \\
\text { Intermediate (3.00): Tracking of conversions within forest } \\
\text { land and other land use (LULUCF) } \\
\text { High (5.00): Spatially explicit tracking of forest land and } \\
\text { other land use (LULUCF) conversions }\end{array}$ \\
\hline & & Emission Factors (EF) & $\begin{array}{l}\text { Low (1.00): IPCC default factors } \\
\text { Intermediate (3.00): Country-specific data for key factors } \\
\text { High (5.00): Detailed national inventory of key C stocks, } \\
\text { repeated measurement of key stocks through time, and } \\
\text { modeling }\end{array}$ \\
\hline & & $\begin{array}{l}\text { Reporting on carbon for } \\
\text { different pools }\end{array}$ & $\begin{array}{l}\text { Very low (1.00): Aboveground biomass (AGB) reported } \\
\text { Low (2.00): AGB and belowground biomass (BGB) reported } \\
\text { Intermediate (3.00): AGB, BGB, and one from the categories } \\
\text { of dead organics (deadwood and litters) and soils reported } \\
\text { High (4.00): AGB, BGB, and two from the categories of } \\
\text { dead organics and soils reported } \\
\text { Very high (5.00): All carbon pools are reported }\end{array}$ \\
\hline & & Reporting on gases & $\begin{array}{l}\text { Low (1.00): No reported gases or } \mathrm{CO}_{2} \text { only } \\
\text { Intermediate }(3.00): \mathrm{CO}_{2} \text { and some of the non- } \mathrm{CO}_{2} \text { gases } \\
\left(\mathrm{CO}, \mathrm{CH}_{4}, \mathrm{~N}_{2} \mathrm{O} \text {, and } \mathrm{NOx}\right) \\
\text { High (5.00): All gases }\end{array}$ \\
\hline & Stepwise approach & Scale of REDD+ activity & $\begin{array}{l}\text { Low (1.00): Project type } \\
\text { Intermediate (3.00): Subnational } \\
\text { High (5.00): National }\end{array}$ \\
\hline & Forest fire & $\begin{array}{l}\text { Fire monitoring and } \\
\text { reporting }\end{array}$ & $\begin{array}{l}\text { Very low (1.00): No information on forest fires or lack of } \\
\text { spatial data } \\
\text { Low (2.00): Monitoring forest fires without reporting } \\
\text { Intermediate (3.00): Reporting the monitored data as a part } \\
\text { of AD } \\
\text { High (4.00): Providing information on emissions caused by } \\
\text { forest fires }\left(\mathrm{CO}_{2} \text { only) }\right. \\
\text { Very high (5.00): Providing information on emissions } \\
\text { caused by forest fires }\left(\mathrm{CO}_{2} \text { and non- } \mathrm{CO}_{2}\right)\end{array}$ \\
\hline
\end{tabular}


Table 2. Cont.

\begin{tabular}{|c|c|c|c|}
\hline & Key Requirement & Indicator & Description (Score) \\
\hline Safeguard & Submission of Safeguard & Frequency & $\begin{array}{l}\text { Low (1.00): Not reported or reported just once in } \\
\text { NCs or other communication channels } \\
\text { Intermediate (3.00): Reported more than once in } \\
\text { NCs or other communication channels but lack of } \\
\text { completion in terms of the context } \\
\text { High (5.00): Completely reported in terms of the } \\
\text { context repetitively in NCs or other communication } \\
\text { channels }\end{array}$ \\
\hline \multirow[t]{2}{*}{ Others } & Consistency & $\begin{array}{l}\text { With National GHG } \\
\text { Inventory }\end{array}$ & $\begin{array}{l}\text { Low (1.00): Mostly inconsistent with AD, EF, and } \\
\text { methodologies used in the National GHG Inventory } \\
\text { according to TAR } \\
\text { Intermediate ( } 3.00) \text { : Some of the items are } \\
\text { inconsistent with the National GHG Inventory } \\
\text { according to TAR } \\
\text { High ( } 5.00) \text { : No inconsistency described according } \\
\text { to TAR }\end{array}$ \\
\hline & Activities & REDD+ activities & $\begin{array}{l}\text { Deforestation } \\
\text { Forest degradation } \\
\text { Conservation of forest carbon } \\
\text { Sustainable management of forest land } \\
\text { Enhancement of forest carbon stocks }\end{array}$ \\
\hline
\end{tabular}

Based on the five issues considered and agreed upon by the UNFCCC Cancun Agreement, the national strategy reporting capabilities of the REDD+ countries were evaluated. In terms of the NFMS, the consistency of forest definition within submitted national reports, in addition to the time series forest area change and remote sensing capabilities used as indicators in [9], were analyzed. To evaluate the ability of carbon stock assessment for setting up the FREL/FRL, the Activity Data (AD) and Emission Factors (EF) were prepared, whereas indicators for reporting on different carbon pools and gases were drawn [9]. The scale of emission activity in the FREL/FRL was also evaluated because developing countries can push for national REDD+ through a stepwise approach, and the capability to monitor and report on forest fires was assessed as well. Furthermore, the Safeguard reporting capabilities were evaluated according to the frequency of reporting, because the WRF requires REDD+ countries to submit the SIS on REDD+ implementation to be presented regularly. For other items, the consistency of the GHG inventory in developing countries was measured on the basis of a Technical Assessment Report (TAR), whereas the number of activities considered REDD+ activities were measured based on FREL/FRL document submissions. Accordingly, the evaluation framework and indicators proposed in [9] were revised and supplemented in light of the key WRF decisions and documents provided by REDD+ countries to the UNFCCC. Assessments were performed based on national reports, submitted in accordance with international consensus.

\subsection{Comparison of MRV Capability by National REDD+ Progress Groups}

We conducted content analysis on the national reports, applied the coding scheme of the WRF, assigned scores corresponding to the indicators, and calculated the scores in Excel 2016. Given that the circumstances for REDD+ implementation differ widely for each country, developing countries can implement REDD+ through a phased approach that consists of readiness, implementation, and RBP stages. The following classifications were created to assess MRV enhancement implications based on the level of REDD+ implementation in developing countries: the countries that submitted only the FREL/FRL were Group I (36 countries); those that registered reduction results after having submitted their FREL/FRL were Group II (5 countries); and those that received RBPs based on their registered reduction results were Group III (6 countries). A comparison of the length of time 
that each group received financial aid from the International Climate Fund was conducted using the Climate Funds Update database of the Overseas Development Institute [15]. To compare the average scores for each group, each MRV evaluation item was standardized to a minimum of one point and a maximum of five points.

\section{Results}

\subsection{Status of REDD+ Readiness: Duration of Foreign Aid Receipt by a Group}

To qualify for RBPs, REDD+ countries must submit documents to the UNFCCC pursuant to the WRF decisions, including the FREL/FRL, and complete technical evaluations, followed by registration of reduction results resulting from REDD+ implementation for the final receipt of RBPs. A total of 47 REDD+ developing countries submitted the FREL/FRL. As shown in Table 3, 36 countries among them submitted the FREL/FRL without reporting emission reduction results and receiving RBPs (Group I). Five countries submitted and reported the results, but had not yet received RPBs (Group II). Only six countries received RBPs after submitting the FREL/FRL and emission reduction results (Group III). All the countries in Group I were funded by the International Climate Fund except for two countries. Four out of five countries in Group II and all the countries in Group III received international financial support. For Groups I, II, and III, the period when receiving funding benefits from the International Fund increased to 4.26 years, 6.25 years, and 7.00 years, respectively. Countries that submitted the results of reduction activities (Group II) or received the RBPs (Group III) were provided with financial support for REDD+ implementation from the international community for longer periods than those that submitted only the FREL/FRL (Group I). It is apparent that international assistance has likely taken a significant role in supporting REDD+ implementation and building capacity in developing countries.

Table 3. Duration of international support received by each group.

\begin{tabular}{cccc}
\hline & $\begin{array}{c}\text { Group I } \\
\text { (FREL/FRL) }\end{array}$ & $\begin{array}{c}\text { Group II } \\
\text { (Results) }\end{array}$ & $\begin{array}{c}\text { Group III } \\
\text { (RBP) }\end{array}$ \\
\hline No. of countries & 36 & 5 & 6 \\
No. of recipient countries & 34 & 4 & 6 \\
Average no. of support years & 4.26 & 6.25 & 7.00 \\
\hline
\end{tabular}

\subsection{National Reports}

A country implementing REDD+ can submit documents to the UNFCCC, including NCs, BURs, and the FREL/FRL, to share information about the latest REDD+ implementation progress. As shown in Table 4, the majority of the countries (36 out of 47 REDD+ countries subjected to the analysis) submitted only the FREL/FRL without reporting emission reduction results or RBPs. Nine of these countries were assigned to the "High" level because they submitted emission reductions at least once. Only two countries submitted reduction results more than once represented as "Very High" level countries. For national reporting capabilities, the intergroup standardization scores for the national strategy level were $2.33,3.67$, and 4.11 for Groups I, II, and III, respectively, with Group III scoring the highest. 
Table 4. Results of MRV capacity evaluation on national reports or submissions.

\begin{tabular}{cccccccc}
\hline \multirow{2}{*}{ Indicator } & Level (Score) & \multicolumn{2}{c}{$\begin{array}{c}\text { Group I } \\
\text { (FREL/FRL) }\end{array}$} & \multicolumn{2}{c}{$\begin{array}{c}\text { Group II } \\
\text { (Results) }\end{array}$} & \multicolumn{2}{c}{$\begin{array}{c}\text { Group III } \\
\text { (RBP) }\end{array}$} \\
\cline { 3 - 8 } & & $\mathbf{n}$ & $\mathbf{\%}$ & $\mathbf{n}$ & $\mathbf{\%}$ & $\mathbf{n}$ & $\%$ \\
\hline & Low (1.00) & 0 & 0 & 0 & 0.00 & 0 & 0.00 \\
Engagementin & Intermediate (2.33) & 36 & 100.00 & 0 & 0.00 & 0 & 0.00 \\
UNFCCC REDD+ & High (3.67) & 0 & 0 & 5 & 100.00 & 4 & 66.67 \\
& Very High (5.00) & 0 & 0 & 0 & 0.00 & 2 & 33.33 \\
& Total & 36 & 100.00 & 5 & 100.00 & 6 & 100.00 \\
\cline { 2 - 7 } & Average Score & \multicolumn{2}{c}{2.33} & & 3.67 & \multicolumn{2}{c}{4.11} \\
\hline
\end{tabular}

\subsection{National Strategy}

As part of REDD+ implementation, countries have to develop and execute national strategies that address five issues: drivers of deforestation and forest devastation, land tenure, forest governance, consideration of gender, and safeguards [8]. As of this work, 33 REDD+ countries had not yet submitted their national strategies, and there was no country for the high level, which indicated that those who addressed all five issues in their national strategies sent submissions, whereas 13 countries addressed more than three issues and were represented as "Intermediate" level countries (Table 5). The intergroup standardization scores for the national strategy level were $0.42,2.00$, and 2.50 for Groups I, II, and III, respectively, with Group III scoring the highest.

Table 5. Results of MRV capacity evaluation on national strategy.

\begin{tabular}{cccccccc}
\hline \multirow{2}{*}{ Indicator } & Level (Score) & \multicolumn{2}{c}{$\begin{array}{c}\text { Group I } \\
\text { (FREL/FRL) }\end{array}$} & \multicolumn{2}{c}{$\begin{array}{c}\text { Group II } \\
\text { (Results) }\end{array}$} & \multicolumn{2}{c}{$\begin{array}{c}\text { Group III } \\
\text { (RBP) }\end{array}$} \\
\cline { 3 - 8 } & & $\mathbf{n}$ & $\mathbf{\%}$ & $\mathbf{n}$ & $\mathbf{\%}$ & $\mathbf{n}$ & $\mathbf{\%}$ \\
\hline & N/A (0.00) & 31 & 86.11 & 1 & 20.00 & 1 & 16.67 \\
The Number of & Intermediate (3.00) & 5 & 13.89 & 3 & 60.00 & 5 & 83.33 \\
Reported Issues & High (5.00) & 0 & 0.00 & 0 & 0.00 & 0 & 0.00 \\
& Total & 36 & 100.00 & 5 & 100.00 & 6 & 100.00 \\
\cline { 2 - 8 } & Average Score & \multicolumn{2}{c}{0.42} & & 2.00 & \multicolumn{2}{c}{2.50} \\
\hline
\end{tabular}

\subsection{National Forest Monitoring System}

The implementation of REDD+ requires setting up the NFMS and providing transparent and consistent data and information for MRV (Decision 11/CP.19). The definition of a forest has to be consistent in the reports submitted by REDD+ countries. Nevertheless, a number of countries (22 countries) were identified as being at the low level, largely as a result of varying definitions of forests in their reports on REDD+, climate change across countries (including NC or BUR), and country reports submitted to the FAO Forest Resource Assessment (Table 6). Seven countries with a consistent definition of forests in all documents submitted were recognized as very high-level countries. Group II had the highest standardization score of 3.67, followed by Group III with 2.56 and Group I with 1.93 .

In REDD+ countries, a key function of the NFMS is monitoring changes in forest surfaces over time. Upon reviewing the ability regarding changes in forest area and remote sensing, 40 countries ranked very well in terms of routinely producing forest area maps that reflected new information after 2000. However, one country was identified as a very low-level country because it lacked a forest cover map, which indicated that the country needed to develop its capabilities. The intergroup standardization score was highest for Group III with 5.00, followed by Group I with 4.75 and Group II with 4.20. 
Table 6. Results of MRV capacity evaluation on the National Forest Monitoring System.

\begin{tabular}{|c|c|c|c|c|c|c|c|}
\hline \multirow{2}{*}{ Indicator } & \multirow{2}{*}{ Level (Score) } & \multicolumn{2}{|c|}{$\begin{array}{c}\text { Group I } \\
\text { (FREL/FRL) }\end{array}$} & \multicolumn{2}{|c|}{$\begin{array}{l}\text { Group II } \\
\text { (Results) }\end{array}$} & \multicolumn{2}{|c|}{$\begin{array}{l}\text { Group III } \\
\text { (RBP) }\end{array}$} \\
\hline & & $\mathbf{n}$ & $\%$ & $\mathbf{n}$ & $\%$ & $\mathbf{n}$ & $\%$ \\
\hline \multirow{6}{*}{$\begin{array}{l}\text { Consistency of forest } \\
\text { definition within } \\
\text { submitted reports }\end{array}$} & Low $(1.00)$ & 19 & 52.78 & 1 & 20.00 & 2 & 33.33 \\
\hline & Intermediate (2.33) & 12 & 33.33 & 1 & 20.00 & 2 & 33.33 \\
\hline & High (3.67) & 2 & 5.56 & 0 & 0.00 & 1 & 16.67 \\
\hline & Very High (5.00) & 3 & 8.33 & 3 & 60.00 & 1 & 16.67 \\
\hline & Total & 36 & 100.00 & 5 & 100.00 & 6 & 100.00 \\
\hline & Average Score & \multicolumn{2}{|c|}{1.93} & \multicolumn{2}{|c|}{3.67} & \multicolumn{2}{|c|}{2.56} \\
\hline \multirow{7}{*}{$\begin{array}{l}\text { Forest area change time } \\
\text { series and remote } \\
\text { sensing capabilities }\end{array}$} & Very Low (1.00) & 1 & 2.78 & 0 & 0.00 & 0 & 0.00 \\
\hline & Low $(2.00)$ & 0 & 0.00 & 1 & 20.00 & 0 & 0.00 \\
\hline & Intermadiate (3.00) & 1 & 2.78 & 0 & 0.00 & 0 & 0.00 \\
\hline & High (4.00) & 3 & 8.33 & 1 & 20.00 & 0 & 0.00 \\
\hline & Very High (5.00) & 31 & 86.11 & 3 & 60.00 & 6 & 100.00 \\
\hline & Total & 36 & 100.00 & 5 & 100.00 & 6 & 100.00 \\
\hline & Average Score & \multicolumn{2}{|c|}{4.75} & \multicolumn{2}{|c|}{4.20} & \multicolumn{2}{|c|}{5.00} \\
\hline
\end{tabular}

\subsection{Safeguard}

To ensure REDD+ is implemented properly, the REDD+ countries should develop a safeguard information system that provides information demonstrating how the safeguards are respected and addressed and submit the SIS (Decision 12/CP.19). Analysis of the frequency of submissions regarding REDD+ Safeguard indicated that the majority of countries (44 countries) fell into the low-level category for not submitting an SIS or submitting it only once via NC and other communication channels since 2014 (Table 7). Safeguard reports have to be submitted every 4 years; however, two countries did not deliver complete reports, whereas one performed a fully complete report repetitively. The intergroup standardization scores of the REDD+ Safeguard levels for Groups I, II, and III were 1.00, 1.40, and 2.00, respectively, with Group III being the highest.

Table 7. Results of MRV capacity evaluation on Safeguard.

\begin{tabular}{cccccccc}
\hline \multirow{2}{*}{ Indicator } & Level (Score) & \multicolumn{2}{c}{$\begin{array}{c}\text { Group I } \\
\text { (FREL/FRL) }\end{array}$} & \multicolumn{2}{c}{$\begin{array}{c}\text { Group II } \\
\text { (Results) }\end{array}$} & \multicolumn{2}{c}{$\begin{array}{c}\text { Group III } \\
\text { (RBP) }\end{array}$} \\
\cline { 2 - 8 } & & $\mathbf{n}$ & $\mathbf{\%}$ & $\mathbf{n}$ & $\mathbf{\%}$ & $\mathbf{n}$ & $\mathbf{\%}$ \\
\hline & Low (1.00) & 36 & 100.00 & 4 & 80.00 & 4 & 66.66 \\
Submission & Medium (3.00) & 0 & 0.00 & 1 & 20.00 & 1 & 16.67 \\
frequency of & High (5.00) & 0 & 0.00 & 0 & 0.00 & 1 & 16.67 \\
Safeguard & Total & 36 & 100.00 & 5 & 100.00 & 6 & 100.00 \\
& Average Score & \multicolumn{2}{c}{1.00} & & 1.40 & & 2.00 \\
\hline
\end{tabular}

\subsection{FREL/FRL}

The WRF decisions require REDD+ countries to prepare the FREL/FRL at a subnational level as a part of the country's national or interim phase and then receive a technical assessment (Decision 13/CP.19). REDD+ countries submit Activity Data (AD), Emission Factors (EF), and carbon pools and gases, which are used to calculate the FREL/FRL at the national or subnational levels and which are evaluated for their transparency and consistency.

\subsubsection{Activity Data}

Many countries (27 in total) were identified as meeting the high-level criteria in terms of utilizing spatial information that incorporated the IPCC land use categories other than forests as activity data for calculating the FREL/FRL, while 19 countries were classified at 
a low level for only considering increases or decreases in forest areas (Table 8). For REDD+ $\mathrm{AD}$ levels, the intergroup standardization scores for Group I, Group II, and Group III were $3.33,3.80$, and 3.00, respectively, with the highest level for Group II.

Table 8. Results of MRV capacity evaluation on the FREL/FRL.

\begin{tabular}{|c|c|c|c|c|c|c|c|}
\hline \multirow{2}{*}{ Indicator } & \multirow[t]{2}{*}{ Level (Score) } & \multicolumn{2}{|c|}{$\begin{array}{c}\text { Group I } \\
\text { (FREL/FRL) }\end{array}$} & \multicolumn{2}{|c|}{$\begin{array}{l}\text { Group II } \\
\text { (Results) }\end{array}$} & \multicolumn{2}{|c|}{$\begin{array}{l}\text { Group III } \\
\text { (RBP) }\end{array}$} \\
\hline & & $\mathbf{n}$ & $\%$ & $\mathbf{n}$ & $\%$ & $\mathbf{n}$ & $\%$ \\
\hline \multirow{5}{*}{ Activity Data (AD) } & Low $(1.00)$ & 15 & 41.67 & 1 & 20.00 & 3 & 50.00 \\
\hline & Intermediate (3.00) & 0 & 0.00 & 1 & 20.00 & 0 & 0.00 \\
\hline & High (5.00) & 21 & 58.33 & 3 & 60.00 & 3 & 50.00 \\
\hline & Total & 36 & 100.00 & 5 & 100.00 & 6 & 100.00 \\
\hline & Average Score & \multicolumn{2}{|c|}{3.33} & \multicolumn{2}{|c|}{3.80} & \multicolumn{2}{|c|}{3.00} \\
\hline \multirow{5}{*}{$\begin{array}{l}\text { Emission Factors } \\
\text { (EF) }\end{array}$} & Low $(1.00)$ & 4 & 11.11 & 0 & 0.00 & 0 & 0.00 \\
\hline & Intermediate (3.00) & 32 & 88.89 & 5 & 100.00 & 6 & 100.00 \\
\hline & High (5.00) & 0 & 0.00 & 0 & 0.00 & 0 & 0.00 \\
\hline & Total & 36 & 100.00 & 5 & 100.00 & 6 & 100.00 \\
\hline & Average Score & \multicolumn{2}{|c|}{2.78} & \multicolumn{2}{|c|}{3.00} & \multicolumn{2}{|c|}{3.00} \\
\hline \multirow{7}{*}{$\begin{array}{c}\text { Reporting on } \\
\text { Carbon for Different } \\
\text { Pools }\end{array}$} & Very Low (1.00) & 0 & 0.00 & 0 & 0.00 & 0 & 0.00 \\
\hline & Low $(2.00)$ & 18 & 50.00 & 3 & 60.00 & 2 & 33.33 \\
\hline & Intermediate (3.00) & 10 & 27.78 & 1 & 20.00 & 1 & 16.67 \\
\hline & High (4.00) & 4 & 11.11 & 1 & 20.00 & 3 & 50.00 \\
\hline & Very High (5.00) & 4 & 11.11 & 0 & 0.00 & 0 & 0.00 \\
\hline & Total & 36 & 100.00 & 5 & 100.00 & 6 & 100.00 \\
\hline & Average Score & \multicolumn{2}{|c|}{2.83} & \multicolumn{2}{|c|}{2.60} & \multicolumn{2}{|c|}{3.17} \\
\hline \multirow{5}{*}{ Reporting on Gases } & Low $(1.00)$ & 28 & 77.78 & 4 & 80.00 & 3 & 50.00 \\
\hline & Intermediate (3.00) & 8 & 22.22 & 1 & 20.00 & 3 & 50.00 \\
\hline & High (5.00) & 0 & 0.00 & 0 & 0.00 & 0 & 0.00 \\
\hline & Total & 36 & 100.00 & 5 & 100.00 & 6 & 100.00 \\
\hline & Average Score & \multicolumn{2}{|c|}{1.44} & \multicolumn{2}{|c|}{1.40} & \multicolumn{2}{|c|}{2.00} \\
\hline \multirow{5}{*}{$\begin{array}{l}\text { Scale of REDD+ } \\
\text { Activity }\end{array}$} & Low $(1.00)$ & 0 & 0.00 & 0 & 0.00 & 0 & 0.00 \\
\hline & Intermediate (3.00) & 5 & 13.89 & 0 & 0.00 & 4 & 66.67 \\
\hline & High (5.00) & 31 & 86.11 & 5 & 100.00 & 2 & 33.33 \\
\hline & Total & 36 & 100.00 & 5 & 100.00 & 6 & 100.00 \\
\hline & Average Score & \multicolumn{2}{|c|}{4.72} & \multicolumn{2}{|c|}{5.00} & \multicolumn{2}{|c|}{3.67} \\
\hline \multirow{7}{*}{$\begin{array}{l}\text { Fire Monitoring and } \\
\text { Reporting }\end{array}$} & Very Low (1.00) & 14 & 38.90 & 1 & 20.00 & 2 & 33.33 \\
\hline & Low $(2.00)$ & 9 & 25.00 & 3 & 60.00 & 1 & 16.67 \\
\hline & Intermediate (3.00) & 3 & 8.33 & 0 & 0.00 & 1 & 16.67 \\
\hline & High (4.00) & 3 & 8.33 & 0 & 0.00 & 0 & 0.00 \\
\hline & Very High (5.00) & 7 & 19.44 & 1 & 20.00 & 2 & 33.33 \\
\hline & Total & 36 & 100.00 & 5 & 100.00 & 6 & 100.00 \\
\hline & Average Score & \multicolumn{2}{|c|}{2.44} & & & & \\
\hline
\end{tabular}

\subsubsection{Emission Factor}

The intermediate level was composed of 43 countries, which used IPCC default factors and country-specific coefficients to calculate their FREL/FRL reports. Four lowlevel countries relied exclusively on IPCC default factors, whereas none of the countries built detailed national inventories through the application of national unique coefficients to time series models (high level) (Table 8). For the REDD+ EF levels, the intergroup standardization scores for Group I, Group II, and Group III were 2.78, 3.00, and 3.00, respectively, with the highest level for Group II and Group III. 


\subsubsection{Reported Carbon Pools}

When establishing the FREL/FRL, dead organics (deadwood and litter) and soil, in addition to above and belowground biomass, could be considered as carbon pools. Most countries (23 in total) were classified as low-level countries, considering only above and belowground biomass whereas four countries were identified as taking all carbon pools into account (Table 8). The highest intergroup standardization was achieved by Group III at 3.17, followed by Group I at 2.83 and Group II at 2.60.

\subsubsection{Reported Gases}

The FREL/FRL reports in REDD+ countries may be submitted in $\mathrm{CO}_{2}$ units, considering the generation of $\mathrm{CO}_{2}$ and non- $\mathrm{CO}_{2}$ gas in the forest sector. Accounting for the majority, the low-level category included 35 countries whose FREL/FRL reports did not mention gas or only mentioned $\mathrm{CO}_{2}$. The countries at the intermediate level, which considered $\mathrm{CO}_{2}$ along with some non- $\mathrm{CO}_{2}$ gases, were composed of 12 countries, and no high-level country considered all gases (Table 8). The MRV-level cross-group standardization score for gas used in FREL/FRL reporting was highest in Group III at 2.00, followed by Group I at 1.44 and Group II at 1.40 .

\subsubsection{Scale of Activity}

The majority of the REDD+ countries (38 countries) were identified as belonging to the high level for their reporting of REDD+ activities at the national level. There were no low-level countries that engaged in project-type REDD+ activities, and a total of nine countries reported subnational levels and were thus classified at the intermediate level (Table 8). The MRV-level intergroup standardization score for the scale of national activity was highest for Group II at 5.00, followed by Group I at 4.72 and Group III at 3.67. This was because the leading countries, including Brazil and Colombia, promoted subnational level REDD+ activities focused on large forest areas in the Amazon region, which are in Group III.

\subsubsection{Fire Monitoring and Reporting}

When calculating the FREL/FRL, only a few countries monitored fires in forests and reported on it; 17 countries either failed to provide information about forest fires or provided spatial information of very low quality. At the intermediate level, four countries presented data on monitoring forest fires in their AD. Three countries provided information on $\mathrm{CO}_{2}$ emissions caused by forest fires and were considered high-level countries, and 10 countries that reported on both $\mathrm{CO}_{2}$ and non- $\mathrm{CO}_{2}$ emissions were classified as very high-level countries (Table 8). The MRV-level intergroup standardization score for fire monitoring and reporting was highest for Group III at 2.83, followed by Group I at 2.44 and Group II at 2.40.

\subsection{Others}

A country's reduction results cannot be recognized through reliable REDD+ levels unless its National GHG Inventory is consistent. According to the Technical Assessment Report (TAR) on FREL/FRL reporting submitted by REDD+ countries, the low level accounted for the largest portion with 26 countries whose elements were mostly incongruent with the National GHG Inventory. There were 14 countries at the intermediate level with some inconsistencies with the National GHG Inventory, whereas 7 countries were at the high level, having no inconsistencies described in the FREL/FRL (Table 9). Groups I, II, and III achieved MRV-level standardization scores of 1.78, 4.20, and 3.00, respectively, for consistency with the National GHG Inventory, with Group II scoring the highest. The number of countries that included 1,2,3,4, and 5 activities in their national REDD+ was $18,10,13,3$, and 3 , respectively. The intergroup standardization scores for Groups I, II, and III were 2.33, 2.00, and 1.67, respectively, with Group I having the highest scores. There was a significant challenge in defining and measuring the reduction results for the five 
activities that are recognized as REDD+, and many countries only focused on reducing deforestation.

Table 9. Results of MRV capacity evaluation for other items.

\begin{tabular}{cccccccc}
\hline \multirow{2}{*}{ Indicator } & Level (Score) & \multicolumn{2}{c}{$\begin{array}{c}\text { Group I } \\
\text { (FREL/FRL) }\end{array}$} & \multicolumn{2}{c}{$\begin{array}{c}\text { Group II } \\
\text { (Results) }\end{array}$} & \multicolumn{2}{c}{$\begin{array}{c}\text { Group III } \\
\text { (RBP) }\end{array}$} \\
\cline { 2 - 8 } & & $\mathbf{n}$ & $\mathbf{\%}$ & $\mathbf{n}$ & $\mathbf{\%}$ & $\mathbf{n}$ & $\mathbf{\%}$ \\
\hline \multirow{3}{*}{ Consistency with } & Intermediate (3.00) & 8 & 22.22 & 2 & 40.00 & 4 & 66.67 \\
National GHG & High (5.00) & 3 & 8.33 & 3 & 60.00 & 1 & 16.67 \\
Inventory & Total & 36 & 100.00 & 5 & 100.00 & 6 & 100.00 \\
\cline { 2 - 9 } & Average Score & \multicolumn{2}{c}{1.78} & & 4.20 & & 3.00 \\
\hline & $1(1.00)$ & 12 & 33.33 & 2 & 40.00 & 4 & 66.66 \\
Number of REDD+ & $2(2.00)$ & 8 & 22.22 & 1 & 20.00 & 1 & 16.67 \\
Activities & $3(3.00)$ & 11 & 30.56 & 2 & 40.00 & 0 & 0.00 \\
& $4(4.00)$ & 2 & 5.56 & 0 & 0.00 & 1 & 16.67 \\
& $5(5.00)$ & 3 & 8.33 & 0 & 0.00 & 0 & 0.00 \\
& Total & 36 & 100.00 & 5 & 100.00 & 6 & 100.00 \\
\cline { 2 - 8 } & Average Score & \multicolumn{2}{c}{2.33} & & 2.00 & & 1.67 \\
\hline
\end{tabular}

\subsection{Overall MRV Capabilities of REDD+ Countries}

The national circumstances for implementing REDD+ and the capabilities for implementing MRV vary across countries. Consequently, a national REDD+ strategy employs a phased approach, which consists of the following steps: the Readiness Phase for laying the foundation for overall REDD+ implementation, the Implementation Phase for operating and monitoring REDD+, and the Results-Based Payment Phase for receiving incentives through the reporting and verification of reduced results.

Overall, although engagement in UNFCCC REDD+ through national reports and the time series forest area change and remote sensing capabilities of the NFMS were competent, it was shown that the capability for reporting on NS and SIS and NFMS's consistency of forest definitions within the submitted reports were low (Figure 1). Among the measurement elements related to the FREL/FRL, MRV capabilities associated with gases, carbon pools, and emission factors were in need of improvement, especially regarding fire monitoring and reporting (Figure 2).

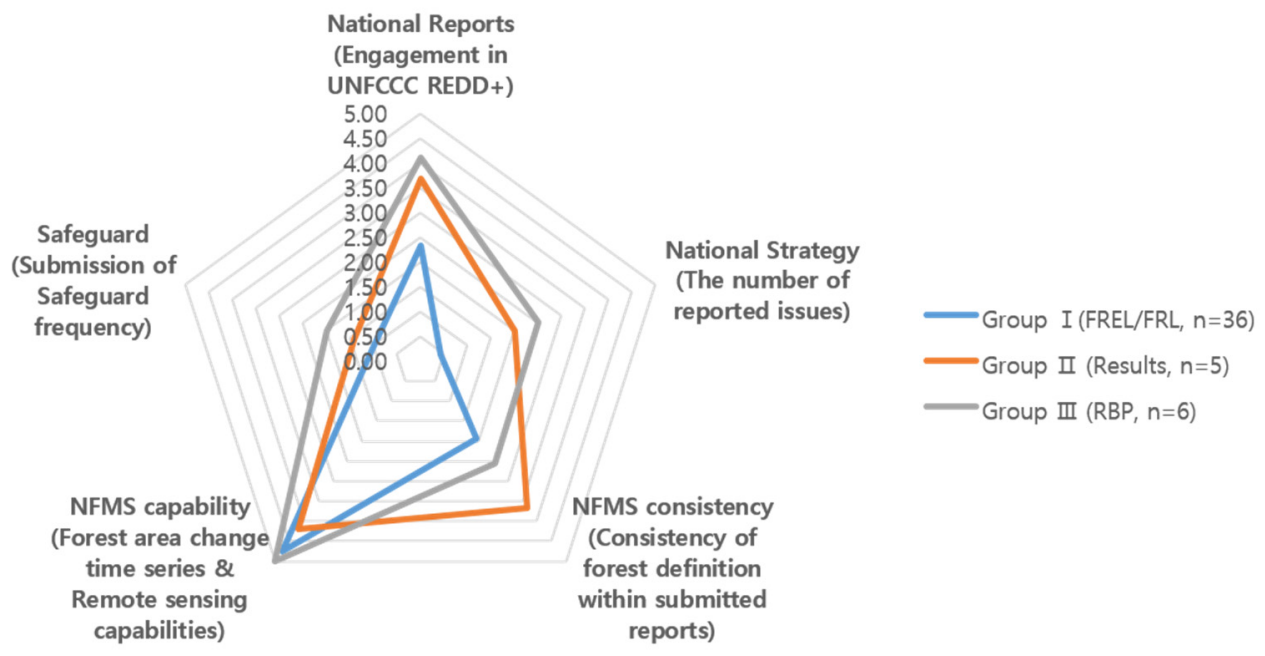

Figure 1. MRV capacities of REDD+ countries by group (National Reports, National Strategy, National Forest Monitoring System, and Safeguard). 


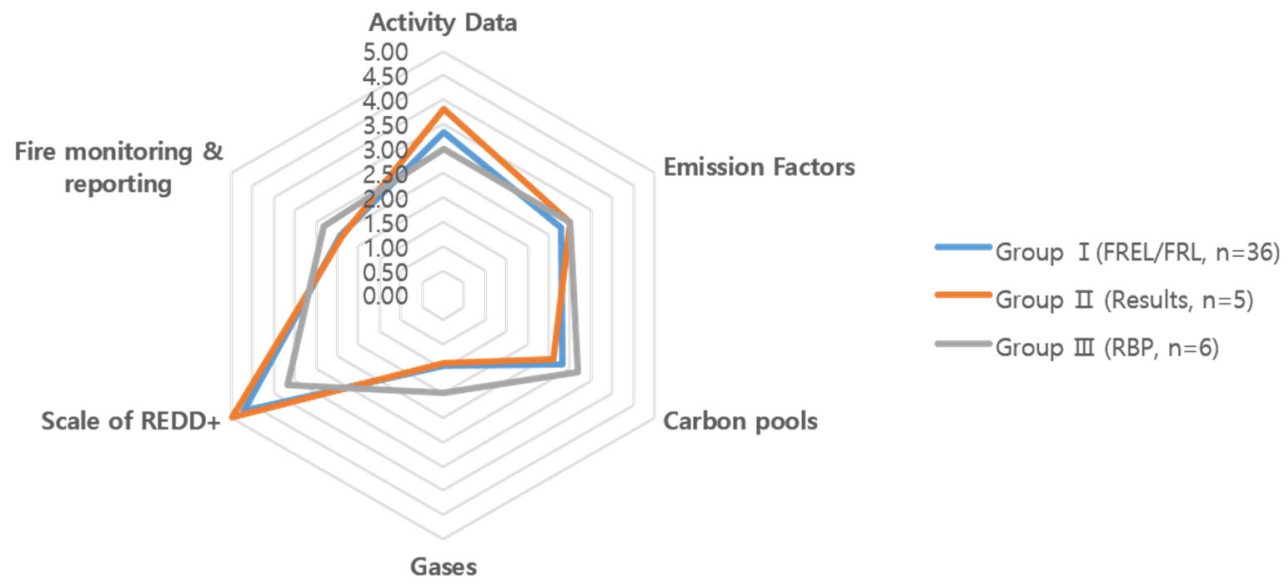

Figure 2. MRV capacities of REDD+ countries by group (FREL/FRL).

In comparison with the Group I countries that submitted only the FREL/FRL, it appears that the MRV capabilities of the Group II countries that registered all the reduction results and the Group 3 countries that received payments for results were higher (Figures 1 and 2). However, the MRV capability as analyzed did not always rank from low to high in the order of Groups I, II, and III. In submitting the FREL/FRL, Group I showed the highest level in terms of the number of REDD+ activities considered (Table 9) for the country REDD+. Furthermore, Group II had higher levels than Group III in Activity Data, the number of activities, the National Monitoring System's consistency of forest definition within the submitted reports, and consistency with the National GHG Inventory by TAR.

\section{Discussion}

Out of the 162 countries that submitted NDCs, 56 countries signed up for REDD+ [16], but only 11 countries had registered reduction results, indicating that most developing countries require much effort and need international support to achieve the MRV levels required by the WRF. Countries that submitted reduction results of REDD+ via BUR or received RBPs secured financial support from the international community for implementing REDD+ for longer periods than those who submitted only the FREL/FRL, demonstrating that international assistance has been highly instrumental in helping developing countries implement REDD+ and enhance their capacities. Additionally, countries that report reduction results through REDD+ could receive RBPs from a variety of sources (both public and private and bilateral and multilateral, including alternative services); however, technical difficulties, such as how developing countries access RBPs and how to apply them, also have to be addressed because diverse resources are involved [17]. Essentially, as stated in the UNFCCC decisions, which are the basis for the Warsaw REDD+ Framework, the Green Climate Fund should serve as a key and single channel for supporting RBPs with a variety of resources to address the challenges REDD+ countries may face related to RBP support $[8,18]$.

Overall, it has been confirmed that Group II and III, which summited reduction results or received RBPs, had higher MRV capabilities than Group I, which submitted only the FREL/FRL. This primarily occurred because Group I countries did not submit national information on National Strategy, Safeguard and NFMS, as Group I countries are responding primarily to the technical assessment of the FREL/FRL, which is most vital for the evaluation of reduction results from REDD+ activities. It appears unlikely that countries in Group I would be limited in submitting reduction results and obtaining RBPs based on these results, given that they have also submitted FREL/FRL reports through technical assessments. For countries in Group I to achieve approval for REDD+ reduction results through BUR-ICA, there is still a need to develop and support the capabilities that enable them to promptly implement other requirements besides FREL/FRL technical assessments. 
In some MRV indicators, Group I exhibited higher MRV levels than Groups II and III, probably because some countries in Groups II and III only had the minimum level of MRV capability required to register reduction results and receive RBPs. For instance, although REDD+ should eventually be implemented on a national scale, and the transparency and reliability of MRV could be enhanced by incorporating the five REDD+ activities, the countries can register reduction results and receive RBPs for performing deforestation only at the subnational scale, as long as they comply with the decisions related to REDD+ under UNFCCC and IPCC guidance. In some cases, Group II had a higher MRV level than Group III because not all countries with higher MRV levels could receive RBPs among the countries that registered reduction results, suggesting that factors external to MRV levels (e.g., international political factors, the willingness of the REDD+ state to receive RBPs, the ability to submit RBP proposals to the international community and so on) may also contribute to their RBP receipt once they have achieved a certain MRV capability [19].

Nearly all REDD+ countries met the required REDD+ MRV level by the WRF; however, some elements were still in need of improvement across most countries, including the rare use of national specific emission factors, a lack of consistency in the activity data, and exclusion of reporting for some carbon pools (e.g., litter, deadwood, and soil) and non- $\mathrm{CO}_{2}$ emissions caused by forest fires. Regarding the consistency of the activity data, the Technical Assessment Report on the FREL/FRL deemed it inconsistent with the Group I National GHG inventory, and the NFMS Consistency of forest definitions within submitted reports also contributed to a poor rating for Group III, scoring 2.56 on average (Table 6, Figure 1). The poor rating was because of changes in the forest definitions of Chile and Costa Rica, as part of the NFMS system's improvement to establish their FREL/FRLs [20-23].

REDD+ countries may be satisfied if they meet a minimum MRV requirement to receive RBPs as an incentive, which is enough of a challenge for some countries. Nevertheless, developing countries are also expected to meet NDCs using REDD+ under the Paris Regime, which requires advancement in the MRV level. Furthermore, the level of REDD+ MRV required to create and transfer ITMOs through REDD+ cooperation based on a cooperative approach might be more stringent than the MRV level previously required to receive RBPs, although UNFCCC negotiations regarding Article 6 of the Paris Agreement are still underway. In the same way that REDD+ implementation under the Kyoto Protocol of developing countries progressed through a phased approach involving the phases of Readiness, Implementation, and RBPs, REDD+ under the Paris Regime requires a higher level of MRV to receive existing RBPs as incentives and to generate and transfer REDD+ ITMOs based on a collaborative approach.

Lastly, there is the urgent task of encouraging the REDD+ countries to set and achieve more ambitious reduction targets. In addition, the non-permanent issue of the REDD+ reductions should also be solved properly. The ultimate goal of the WRF for the REDD+ countries is to achieve net-zero emissions from their forests, decreasing the emissions gradually by updating their FREL/FRLs. Emission reduction reversals, however, may occur because of various deforestation drivers, such as policy revisions, governmental regime changes, and economic developments in the REDD+ countries [24]. Therefore, to receive RBPs, achieve NDCs and generate internationally transferred mitigation outcomes through REDD+ activities, the REDD+ countries and their partners should make efforts to address this non-permanent issue.

\section{Conclusions}

The REDD+ activities for preserving and conserving carbon stored in forests to reduce GHG emissions and enhance the carbon sink function of forests are expected to serve as an important means of achieving climate goals. However, it is essential that a reliable MRV system is in place to accurately measure and reflect the contribution of REDD+ activities to respond to climate change. In this study, a set of criteria was devised and applied to REDD+ developing countries to assess their REDD+ MRV capabilities. 
A total of 47 REDD+ countries submitted FREL/FRL reports (Group I), while 5 countries fulfilled the WRF requirements and registered their REDD+ reduction results (Group II), and 6 received RBPs (Group III). Under the decisions related to the WRF, REDD+ countries have to implement MRV frameworks for NSAP, NFMS, the FREL/FRL, and SIS. However, it was found that NSAP and SIS were weak for MRV levels in general. From the longest to the shortest, the periods for which the International Fund provided support were arranged in the order of Group III, II, and I, verifying the relative importance of international support. From the highest to the lowest, the overall MRV capability was also arranged in the order of Group III, II, and I, although Group I or Group II was at a higher level than the other groups in some elements. This clarifies that REDD+ countries could receive RBPs from the international community if their reduction results were approved through technical assessments by the UNFCCC, irrespective of incompleteness in some MRV elements.

REDD+ countries in the Readiness Phase (Group I) would aim to have the MRV capabilities of Groups II and III to receive RBPs, and international support for REDD+ MRV capacity building could enable them to do. However, in addition to the receipt of RBPs, REDD+ should be reflected in the NDC as consistent reduction results at the national GHG inventory level, and the advancement of REDD+ MRV is expected to be a necessary and sufficient condition for REDD+ cooperation under the Paris Agreement cooperative approach framework.

For the following groups, international cooperation is essential. Countries in the Readiness Phase need to be supported with the establishment of an MRV framework, which will enable them to achieve REDD+ to receive RBPs and be reflected in the NDCs. For REDD+ countries that have thus far met the WRF requirements, the REDD+ scope needs to be upscaled to national levels, and the MRV system should be further advanced to establish a cooperative approach system that can achieve more ambitious reduction targets through forests.

Author Contributions: Conceptualization, R.K. and E.C.; methodology, J.P., S.K.L., D.-h.K. and S.C.; validation, R.K. and J.P.; formal analysis, D.-h.K. and S.C.; writing-original draft preparation, D.-h.K.; writing-review and editing, R.K. and E.C.; visualization, D.-h.K.; supervision, R.K. and Y.S. All authors have read and agreed to the published version of the manuscript.

Funding: This study was carried out with the support of the "R\&D Program for Forest Science Technology (Project No. AP00000523)", provided by the Korea Forest Service (Korea Forestry Promotion Institute) and funded by the National Institute of Forest Science (NIFoS), grant number FM0200-2019-01.

Institutional Review Board Statement: Not applicable.

Informed Consent Statement: Not applicable.

Conflicts of Interest: The authors declare no conflict of interest.

\section{References}

1. United Nations Framework Convention on Climate Change (UNFCCC). Paris Agreement; United Nations Framework Convention on Climate Change (UNFCCC): Paris, France, 2015.

2. Millar, R.J.; Fuglestvedt, J.S.; Friedlingstein, P.; Rogelj, J.; Grubb, M.; Matthews, D.; Skeie, R.B.; Forster, P.M.; Frame, D.; Allen, M.R. Emission budgets and pathways consistent with limiting warming to $1.5^{\circ} \mathrm{C}$. Nat. Geosci. 2017, 10, 741-747. [CrossRef]

3. Goodwin, P.; Katavouta, A.; Roussenov, V.; Foster, G.L.; Rohling, E.J.; Williams, R.G. Pathways to $1.5^{\circ} \mathrm{C}$ and $2{ }^{\circ} \mathrm{C}$. warming based on observational and geological constraints. Nat. Geosci. 2018, 11, 102-107. [CrossRef]

4. Tokarska, K.B.; Gillett, N.P. Cumulative carbon emissions budgets consistent with $1.5^{\circ} \mathrm{C}$ global warming. Nat. Clim. Change 2018, 8, 296-299. [CrossRef]

5. Le Quéré, C.; Andrew, R.M.; Friedlingstein, P.; Sitch, S.; Pongratz, J.; Manning, A.C.; Korsbakken, J.I.; Peters, G.P.; Canadell, J.G.; Jackson, R.B.; et al. Global carbon budget 2017. Earth Syst. Sci. Data Discuss. 2018, 10, 405-448. [CrossRef]

6. Pan, Y.; Birdsey, R.A.; Fang, J.; Houghton, R.; Kauppi, P.E.; Kurz, W.A.; Phillips, O.L.; Shvidenko, A.; Lewis, S.L.; Canadell, J.G.; et al. A large and persistent carbon sink in the world's forests. Science 2011, 333, 988-993. [CrossRef] [PubMed] 
7. Pan, Y.; Birdsey, R.A.; Phillips, O.L.; Jackson, R.B. The structure, distribution, and biomass of the world's forests. Annu. Rev. Ecol. Evol. Syst. 2013, 44, 593-622. [CrossRef]

8. United Nations Framework Convention on Climate Change (UNFCCC). Decision 9/CP.19, Work Programme on Results-Based Finance to Progress the Full Implementation of the Activities Referred to in Decision 1/CP.16, Paragraph 70; United Nations Framework Convention on Climate Change (UNFCCC): Paris, France, 2010.

9. Herold, M. An Assessment of National Forest Monitoring Capabilities in Tropical Non-Annex I Countries: Recommendations for Capacity Building; The Government of Norway: Oslo, Norway, 2009.

10. Till, N.; Zoltan, S.; Corinna, S.; Esther, M.; Joachim, R.; Johannes, B.; Karsten, D.; Katja, O.; Sandro, F. Assessing progress in MRV capacity development: Experience with a scorecard approach. Clim. Policy 2015, 17, 203-212.

11. Andoh, J.; Lee, Y. National REDD+ strategy for climate change mitigation: A review and comparison of developing countries. Sustainability 2018, 10, 4781. [CrossRef]

12. United Nations Framework Convention on Climate Change (UNFCCC). Decision 10/CP.19 Coordination of Support for the Implementation of Activities in Relation to Mitigation Actions in the Forest Sector by Developing Countries, Including Institutional Arrangements; United Nations Framework Convention on Climate Change (UNFCCC): Paris, France, 2013.

13. United Nations Framework Convention on Climate Change (UNFCCC). Decision 12/CP.17 Guidance on Systems for Providing Information on How Safeguards are Addressed and Respected and Modalities Relating to Forest Reference Emission Levels and Forest Reference Levels as Referred to in Decision 1/CP.16; United Nations Framework Convention on Climate Change (UNFCCC): Paris, France, 2021.

14. United Nations Framework Convention on Climate Change (UNFCCC). Decision 14/CP.19 Modalities for Measuring, Reporting and Verifying; United Nations Framework Convention on Climate Change (UNFCCC): Paris, France, 2013.

15. Overseas Development Institute (ODI). Climate Funds Update; Overseas Development Institute (ODI): London, UK, 2020.

16. Hein, J.; Guarin, A.; Frommé, E.; Pauw, P. Deforestation and the Paris climate agreement: An assessment of REDD+ in the national climate action plans. For. Policy Econ. 2018, 90, 7-11. [CrossRef]

17. Charlene, W.; Sejal, P.; Liane, S. Climate Finance Thematic Briefing: REDD+ Finance; Overseas Development Institute (ODI): London, $\mathrm{UK}, 2016$.

18. Green Climate Fund. Accelerating REDD+ Implementation; Green Climate Fund: Incheon, Korea, 2019.

19. Kim, D.-H.; Kim, D.-H.; Kim, H.S.; Kim, S.-I.; Lee, D.-H. Determinants of bilateral REDD+ cooperation recipients in Kyoto Protocol regime and their implications in Paris Agreement regime. Forests 2020, 11, 751. [CrossRef]

20. Cano, J.; Sartori, A.; Quintanilla, O.; Oyarzún, V. Forest Reference Emission Level/Forest Reference Level of National Forests in Chile; The National Forest Corporation (CONAF): Santiago, Chile, 2016.

21. Ministry of Environment and Energy of Costa Rica. Modified REDD+ Forest Reference Emission Level/Forest Reference Level (FREL/FRL); Ministry of Environment and Energy: San Jose, Costa Rica, 2016.

22. United Nations Framework Convention on Climate Change (UNFCCC). Report on the Technical Assessment of the Proposed Forest Reference Emission Level of Chile Submitted in 2016, FCCC/TAR/2016/CHL; United Nations Framework Convention on Climate Change (UNFCCC): Paris, France, 2016.

23. United Nations Framework Convention on Climate Change (UNFCCC). Report on the Technical Assessment of the Proposed Forest Reference Emission Level of Costa Rica Submitted in 2016, FCCC/TAR/2016/CRI; United Nations Framework Convention on Climate Change (UNFCCC): Paris, France, 2016.

24. Mikaela, W.; Goldman, E. Primary Rainforest Destruction Increased 12\% from 2019 to 2020; World Resources Institute: Washington, DC, USA, 2021. 